\title{
Recenzja \\ Zbigniew Tarkowski, Ewa Humeniuk: \\ Shyness, logophobia, mutism. Diagnosis and therapy \\ [Nieśmiałość, logofobia, mutyzm. Diagnoza i terapia]. New York, Nova Science Publishers, 2020, 221 stron
}

Sięgając po recenzowaną monografię, spodziewałam się, że perspektywa badawcza zaproponowana przez autorów okaże się prowokująca do przemyśleń. Lektura potwierdziła te przypuszczenia. Przeważnie nieśmiałość, logofobia i mutyzm są omawiane osobno, a w tej publikacji porównuje się je i szuka zależności.

Monografia jest podzielona na trzy zasadnicze części. Rozpoczyna ją rozdział poświęcony nieśmiałości. Autorzy omawiają jej różne definicje oraz wskazują na różnice pomiędzy nieśmiałością a lękiem społecznym, introwersją, wycofaniem społecznym, onieśmieleniem, zakłopotaniem, wstydem i zahamowaniem. Opisują społeczne funkcjonowanie osób nieśmiałych i wskazują na ich trudności komunikacyjne. Na koniec stawiają zasadnicze pytanie: czy skrajna postać nieśmiałości nie jest formą mutyzmu selektywnego?

W części drugiej monografii, poświęconej logofobii, znajdziemy interesującą próbę systematyzacji zachowań lękowych. Autorzy zauważają, że w lęku społecznym, komunikacyjnym, tremie i logofobii występują podobne objawy fizjologiczne, a cech różnicujących je należy się doszukiwać na poziomie poznawczym i behawioralnym. W tej części pracy została omówiona koncepcja logofobii sformułowana przez Zbigniewa Tarkowskiego.

Trzecia część monografii została poświęcona mutyzmowi, którego podstawowym objawem jest milczenie całkowite lub wybiórcze. Autorzy szeroko piszą o funkcji i przyczynach milczenia, wskazując na jego aspekty pozytywne i negatywne. Wyróżniają różne rodzaje mutyzmu, szczegółowo omawiają podział zaproponowany przez Tarkowskiego i Anetę Kiepielę-Koperek - mutyzmu selektywnego na: sytuacyjny, lękowy, traumatyczny i opozycyjny oraz podają kryteria diagnozy dyferencjalnej. Wskazują też na różnice między mutyzmem wybiórczym a lękiem komunikacyjnym, fobią przedszkolną i szkolną, opóźnionym rozwojem mowy, niepełnosprawnością intelektualną, zaburzeniami ze spektrum autyzmu. 
W trzeciej części monografii omówiono także podstawowe strategie terapii mutyzmu selektywnego, czyli podejście behawioralne, poznawczo-behawioralne, psychodynamiczne, rodzinne, farmakologiczne oraz łączone. W nawiązaniu do nich przedstawiono nowatorską metodę terapii mutyzmu opracowaną przez Tarkowskiego. Opiera się ona na założeniu, że mutyzm selektywny to zaburzenie wieloczynnikowe oraz wielopostaciowe. Celem diagnozy jest ustalenie nie tylko przejawów i okoliczności samego milczenia, ale przede wszystkim jego przyczyn. Terapia metodą Tarkowskiego jest dostosowana do specyfiki mutyzmu selektywnego, wymagającego odpowiedniego podejścia. Inaczej bowiem prowadzi się terapię w przypadku mutyzmu sytuacyjnego, lękowego, traumatycznego, opozycyjnego. Terapeuta przyjmuje postawę akceptacji wobec dziecka, ale nie wobec jego milczenia, które jednak toleruje w pierwszej fazie leczenia. Leczenie dzieli się na trzy zasadnicze fazy: początkową, środkową i końcową. Niezwykle istotna jest pierwsza sesja terapeutyczna, której cel stanowią: nawiązanie kontaktu i budowanie relacji terapeutycznej, określenie motywacji do terapii, dokonanie wstępnej diagnozy, rozpoznanie problemu dziecka, określenie reakcji poznawczych, behawioralnych i emocjonalnych na przedłużające się milczenie dziecka. Ważne jest również zawarcie kontraktu terapeutycznego, obejmującego całą rodzinę, oraz czynne włączenie do terapii ojca (ojcowie na ogół wykazują mniejsze zaangażowanie niż matki). Pierwsze sesje terapeutyczne są prowadzone zarówno w miejscach, w których dziecko nie mówi, jak i w tych, w których nie przejawia takich trudności.

Środkowy etap terapii ma na celu pogłębienie relacji terapeutycznej opartej na współpracy, rozwijanie komunikacji bezsłownej, wyzwalanie potrzeby mówienia i stopniowe przygotowanie do zakończenia terapii. Autorzy podają przykłady terapii prowadzonej w gabinecie, placówce edukacyjnej, ośrodku terapeutycznym lub w kilku tych miejscach jednocześnie. Podkreślają duże walory opowiadań terapeutycznych. Przedstawiają przykłady ich wykorzystania, ze zwróceniem uwagi na istotną w terapii możliwość identyfikowania się przez milczące dziecko z bohaterem historii. Podstawowe znaczenie ma rozwinięcie bajki terapeutycznej zgodnie z rozpoznanym rodzajem mutyzmu selektywnego. Twórca metody, Zbigniew Tarkowski, proponuje, aby „ciszę w czasie sesji terapeutycznej wypełnić twórczością dziecka, którą można analizować pod względem treści i formy”. W publikacji szczegółowo omówiono również procedury behawioralne przewidziane w prezentowanej terapii.

Tarkowski zaprasza całą rodzinę do ośrodka terapeutycznego. Dzięki temu ma on możliwość przyjrzenia się z bliska dziecku oraz jego najbliższym, pogłębienia diagnozy oraz proponowania wprowadzenia zmian w życiu rodzinnym.

$\mathrm{Na}$ ogół terapia jest prowadzona wówczas, gdy dziecko nie mówi, a oczekuje się od niego ustnych wypowiedzi. Tarkowski proponuje zmianę tego podejścia i przeniesienie terapii do miejsca, gdzie dziecko mówi, na przykład do rodzinnego 
domu. Takie podejście zasadniczo zmienia strukturę i dynamikę terapii. W jej końcowej fazie zmierza się do zwiększenia gotowości komunikacyjnej dziecka z mutyzmem, utrwalenia opanowanych wcześniej umiejętności komunikacyjnych, przygotowania do zmiany, jaką będzie zakończenie spotkań terapeutycznych, oraz sprawdzenia efektów terapii. O rezultatach decyduje wiele czynników, a przede wszystkim trafność rozpoznania rodzaju mutyzmu selektywnego i dostosowanie do niego przebiegu leczenia.

Na podkreślenie zasługuje to, że poszczególne etapy terapii są dodatkowo przedstawione na przykładzie konkretnych jej scenariuszy, z opisem postępowania terapeuty oraz zachowania dziecka i jego rodziny. $Z$ wielu względów wartościowy jest również rozdział przedstawiający studia przypadków dzieci z mutyzmem wybiórczym. Został on opracowany przez polskich terapeutów, zaproszonych do współpracy. Taka promocja krajowych osiągnięć terapeutycznych jest wyjątkowa i zasługuje na uznanie.

\section{EDYTA ŚNISZEWSKA}

Zakład Patologii i Rehabilitacji Mowy, Katedra Psychologii, Uniwersytet Medyczny w Lublinie (D) https://orcid.org/0000-0002-6456-1697 